\title{
ALKALINE PROTEASE, AMYLASE AND CELLULASE ACTIVITIES OF YELLOW RASBORA, Rasbora lateristriata Blkr., AT DIFFERENT FEEDING LEVELS
}

\section{AKTIVITAS PROTEASE ALKALIN, AMILASE DAN SELULASE IKAN LUNJAR, Rasbora Lateristriata Blkr., PADA LEVEL PEMBERIAN PAKAN BERBEDA}

\author{
Untung Susilo $^{1^{*}}$, Purnama Sukardi ${ }^{2}$, Ridwan Affandi ${ }^{3}$ \\ ${ }^{1}$ Faculty of Biology, Universitas Jenderal Soedirman, Purwokerto, Indonesia \\ ${ }^{2}$ Fakulty of Fisheries and Marine Science, Universitas Jenderal Soedirman, Purwokerto, Indonesia \\ ${ }^{3}$ Fakulty of Fisheries and Marine Science, Bogor Agricultural University, Bogor, Indonesia \\ *e-mail: susilo.utg@gmail.com
}

Received 26 July 2016; Accepted 27 October 2016; Available online 29 November 2016

\begin{abstract}
Alkaline protease, amylase and cellulase activities of the digestive organ of yellow rasbora, Rasbora lateristriata Blkr., was evaluated with four different feeding levels of $0.34 \mathrm{~g}$ protein $+0.03 \mathrm{~g}$ fiber, $1.01 \mathrm{~g}$ protein $+0.10 \mathrm{~g}$ fiber, $1.69 \mathrm{~g}$ protein $+0.16 \mathrm{~g}$ fiber and $2.36 \mathrm{~g}$ protein $+0.23 \mathrm{~g}$ fiber/day $/ 100 \mathrm{~g}$ fish biomass. A total of 280 fish with average body weight of $0.71 \pm 0.06 \mathrm{~g}$ were used in this study. The results showed that the difference in the feeding levels caused in a significant difference in trypsin and chymotrypsin activities $(\mathrm{P}<$ $0.05)$, but not for amylase and cellulase activities $(\mathrm{P}>0.05)$. In conclusion, protein digestion capacity increased, but not to the digestion of starch and fiber in response to different feeding levels and the optimal feeding level for yellow rasbora was 1,01 $\mathrm{g}$ protein $+0,10 \mathrm{~g}$ fiber/day/100 $\mathrm{g}$ fish biomass.
\end{abstract}

Keywords :Amylase, cellulase, chymotrypsin, rasbora, trypsin

\begin{abstract}
ABSTRAK
Aktivitas protease alkalin, amilase dan selulase organ pencernaan ikan lunjar, Rasbora lateristriata Blkr., telah dievaluasi dengan empat tingkat pemberian pakan yang berbeda $(0,34 \mathrm{~g}$ protein $+0,03 \mathrm{~g}$ serat, protein $1,01 \mathrm{~g}+0,10 \mathrm{~g}$ serat, $1,69 \mathrm{~g}$ protein $+0,16 \mathrm{~g}$ serat dan 2,36 g protein $+0,23 \mathrm{~g}$ serat / hari / $100 \mathrm{~g}$ biomassa ikan). Sebanyak 280 individu ikan dengan berat badan rata-rata $0.71 \pm 0.06 \mathrm{~g}$ telah digunakan dalam penelitian ini. Hasil penelitian menunjukkan bahwa perbedaan level pemberian pakan menghasilkan perbedaan yang signifikan dalam aktivitas tripsin dan kimotripsin $(\mathrm{P}<0,05)$, tetapi tidak untuk aktivitas amilase dan selulase $(\mathrm{P}>0,05)$. Kesimpulan, kapasitas pencernaan protein meningkat, tetapi tidak untuk pencernaan pati dan serat dalam menanggapi level pemberian pakan berbeda dan level pakan optimum untuk ikan lunjar adalah $1,01 \mathrm{~g}$ protein $+0,10 \mathrm{~g}$ serat / hari / $100 \mathrm{~g}$ biomassa.
\end{abstract}

Kata kunci : Amilase, kimotripsin, rasbora, sellulase, tripsin

\section{INTRODUCTION}

Yellow rasbora in Indonesia known as lunjar, has a moderate economic value (Dina Boer, and Butet, 2011; Rosadi, Endang, Setyohadi, \& Bintoro, 2014). This economic value leads to high exploitation which may decrease its production. It has been reported that yellow rasbora production in Agam, Sumatera Island has been dropped from 307.05 tons in 2006 to 142.21 tons in 2007 (Dina, et al., 2011). This happen also in Kalimantan Island (Sulistiyarto, 
2012) and West Java (Astuti, 2012). Therefore, more attention should be paid on this yellow rasbora Rasbora lateristriata Blkr. to avoid extinction. In first study domestication was successfully performed in the wet laboratory of Faculty of Biology Unsoed, Purwokerto. However, this effort need to be optimized by providing scientific data, especially on nutritional physiology. Therefore, it is important to study a nutritional physiology of yellow rasbora, especially the ability of yellow rasbora on nutrients utilization.

The ability of fish to utilize the nutrients depends on the ability of digestion which is reflected by digestive enzyme activity. Therefore, the study on digestive capacity which is reflected in the activity of the digestive enzyme is required to harmonize the digestive capability and the consumed feed to improve feeding efficiency.

Various digestive enzymes can be found throughout the gastrointestinal tract with different activities, but in general they can be classified as digestive enzymes of protease, lipase and carbohydrase. Alkaline protease activity such as trypsin and chymotrypsin are found in intestine and pancreas of herbivores, omnivores and carnivores. Previous studies had demonstrated the activity of trypsin and chymotrypsin in the pancreas and intestine in a variety of fish such as Parachanna obscura (Odedeyi, 2007), Mormyrus rume (Odedeyi \& Fagbenro, 2010), herbivores and carnivores stomachless fish (Day et al., 2011), Solea senegalensis (Rodiles, Santigosa, Herrera, Hachero-Cruzado, \& Cordero, 2012), Diplodus sargus (Yufera, Moyono, Astola, Pousau-Ferreira, \& Martinez-Rodriguez, 2012), Horabagrus brachysoma (Prasad \& Suneesha, 2013), Lates niloticus (Namulawa et al., 2013), Etroplus suratensis and Oreochromis mossambicus (Sankar et al., 2014).

Trypsin has an optimum $\mathrm{pH}$ of 8.0 in Theragra chleogramma (Kishimura,
Klomklao, Benjakul, \& Chun, 2008), but in Glyptosternum maculatum (carnivores) the optimal $\mathrm{pH}$ for proteases found along the intestine are $\mathrm{pH} 9.0$ to 10.0, (Xiong, Xie, Zhang, \& Liu, 2009), and the same phenomenon is also observed in Zosterisessor ophiocephalus, Raja clavata and Scorpaena scrofa which has alkaline protease activity at the optimum $\mathrm{pH}$ 8-10 (Nasri et al., 2011). The end product of trypsin and chymotrypsin digestion in the form of peptide fragments will be the substrate for the aminopeptidase and carboxypeptidase.

Activity of carbohydrase, such as amylase, is also found in a variety of fish such as Perca fluvialis, Salvelinus alpinus, Mormyrus rume, and New Zealand herbivorous fish (Skea, Mounfort, and Clements, 2007; Odedeyi \& Fagbenro, 2010 ; Langeland, Lindberg, and Lundh, 2013), but amylase activity is not found in three species of tuna, Thunnus albacares, Katsuwonus pelamis and Thunnus tonggol (Prasertsan \& Prachumratama, 2008). In three Cyprinidae species, it has also shown that $\alpha$-amylase activity is influenced by feeding habits and $\alpha$ amylase in herbivorous fish is more superior than in omnivores and carnivores (Al-Tameemi, Aldubaikul, and Salman, 2010).

Amylase activity is also associated with the fish food category. Herbivorous fish such as prickleback fishes (Cebidichthys violaceus) has $\alpha$-amylase activity higher than carnivorous fish (German, Horn, and Gawlicka, 2004). The same phenomenon is also found in halfbeaks fish (Hemiramphidae), a herbivorous fish, in which maltase activity is not different from carnivorous fish, but has a higher $\alpha$-amylase activity (Day et al., 2011). In Lates niloticus, amylase activity is also observed in the digestion system (Namulawa et al., 2013). Amylase is active in neutral to alkaline, such as those found in four species of herbivorous minnows fish (German, 2009), Betta splendens (Thongprajukae, Kovitvadhi, 
Engkagul, and Rungruangsak-Torrissen, 2010) and Rhamdia quelen (Lazzari et al., 2010), three species of cyprinid (Al Tameemi et al., 2010) and Pangasianodon gigas (Tongsiri, Mang-Amphan, and Peerapornpisal, 2010).

Fish generally do not secrete cellulase, so the ability to hydrolyze the fiber in the diet is very low. The fish ability to digest fiber is associated with symbiotic microbes that have the ability to produce cellulase in the digestive tract, such as those found in Labeo rohita and Channa punctatus (Kar \& Ghosh, 2008). The activities of cellulase is also observed in Pangasianodon gigas (Tongsiri et al., 2010) and Diplodus puntazzo (Savona, Tramati, and Mazzola, 2011).

Evaluation of the relationship between food quality and quantity on digestion capacity have also been carried out on several fish species, such as on Labeo rohita (Debnath et al., 2007), Salmo salar (Kraugerud et al., 2007), tilapia, Oreochromis niloticus (Chan, Lee, Cheng, Hsieh, and Weng, 2007), Betta splendens (Thongprajukaew, Kovitvadhi, Kovitvadhi, Somsueb, and RungruangsakTorrissen, 2011). and Sparus sole senegalensis (Rodiles et al. 2012).

However, the study on the relationships between different feeding levels and digestive enzyme activity, especially in yellow rasbora, Rasbora lateristriata Blkr., has never been done. Information related to a response of digestive enzyme to feeding levels of yellow rasbora is needed to understand the capacity of fish digestion. Therefore, this study aimed to determine the activity of alkaline protease (trypsin and chymotrypsin), amylase and cellulase in response to different feeding levels on yellow rasbora.

\section{EXPERIMENTAL SECTION}

\section{Materials and Instruments}

Tris (hydroxymethyl) aminomethane (Tris) (Sigma-Aldrich, ACS Reagent, >99.8\%), hydrochloric acid (Merck, 36.5-38.0\%), 3,5-dinitrosalicylic acid (DNS) (Sigma-Aldrich, >98\%), N $\alpha$ p-tosyl-L-arginine hydrochloride methyl ester (Sigma-Aldrich, AG), N-benzoyl-Ltyrosine ethyl ester (Sigma-Aldrich, AG), Sodium acetate (Merck, AG), Folin \& Ciocalteu's phenol reagent (SigmaAldrich), Starch (Bio Basic Canada, High Purity), carboxymethylcellulose (Merck, Technical Grade), centrifuge (Eppendorf, 5415 R), spectrophotometry (Hitachi, U2900), single channel pipette (Serana), water bath (JEIO-TECH, WB-20E).

\section{Experimental Design}

The study was carried out by experimental methods using completely randomized design (CRD) with four treatments and three replications. The treatment was as follow:

A. feed containing $0.34 \mathrm{~g}$ protein $+0.03 \mathrm{~g}$ fiber/day/100 g biomass; B. (1.01 g protein+0.10 g fiber/day/100 $\mathrm{g}$ biomass); C. $(1.69 \mathrm{~g}$ protein $+0.16 \mathrm{~g}$ fiber/day/100 g biomass); D. (2.36 g protein $+0.23 \mathrm{~g}$ fiber/day/100 $\mathrm{g}$ biomass).

A total of 280 fish with an average weight of $0.71 \pm 0.06 \mathrm{~g}$ were used in this study. Fish samples were obtained from the wet laboratory of Faculty of Biology, Unsoed. Fish were reared for one month in four concrete tanks $\left(1.0 \times 1.2 \mathrm{~m}^{2}\right)$ filled with $0.24 \mathrm{~L}$ of water and were fed artificial feed. During the experiment, fish were fed two times a day in accordance with the treatment applied. Proximate analysis based on dry matter of artificial feed showed in Table 1.

Table 1. Mean nutrient content of the artificial feed

\begin{tabular}{ccccccc}
\hline Water & Dry Matter & \multicolumn{6}{c}{ Dry weight } \\
\cline { 3 - 7 }$(\boldsymbol{\%})$ & $(\boldsymbol{\%})$ & Crude protein & Crude fat & Crude fiber & Ash & NFE \\
\hline 9.85 & & 33.71 & 5.67 & 3.27 & 8.55 & 38.96 \\
\hline
\end{tabular}




\section{Preparation of Tissue Homogenate}

In the final experiment, fish in each concrete tank was divided into six pool samples. The digestive organs were taken out from fish in pool sample (10-12 fish) and were homogenized in ice-cold buffer solutions (50 mM Tris- $\mathrm{HCl}, \mathrm{pH} 7.5)$ at a ratio of 1: 9 , and than were centrifuged at $12,000 \mathrm{rpm}$ for 15 minutes at $4{ }^{\circ} \mathrm{C}$. All supernatant were collected in $1500 \mu \mathrm{L}$ eppendorf tubes, and then stored at $-80{ }^{\circ} \mathrm{C}$ for future enzymatic assay. Protein contents in the supernatant were measured using Lowry method (Thongprajukaew, Kovitvadhi, Engkagul, \& RungruangsakTorrissen, 2010) with albumin as a standard.

\section{Enzyme Activity Essay}

\section{Trypsin activity essay}

Modification method of Kishimura, (2008) using No-p-tosyl-L-argnine hydrochloride methyl ester (TAME) was used to measure trypsin activity. $10 \mathrm{mM}$ TAME substrate was prepared by dissolving $37.9 \mathrm{mg}$ TAME into $10 \mathrm{~mL}$ of double-distilled water. Buffer $46.0 \mathrm{mM}$ Tris- $\mathrm{HCl}$ at $\mathrm{pH} 8.1$ containing $11.5 \mathrm{mM}$ $\mathrm{CaCl}_{2}$ prepared by dissolving $1.39 \mathrm{~g}$ Tris into double-distilled water to a volume of $200 \mathrm{~mL}$, then added $6.4 \mathrm{~mL}$ of $5 \%(\mathrm{w} / \mathrm{v})$ $\mathrm{CaCl}_{2}$. The solution was then adjusted its $\mathrm{pH}$ by adding a solution of $1 \mathrm{~N} \mathrm{HCl}$ until the $\mathrm{pH}$ reached 8.1. The solution was then diluted to a volume of $250 \mathrm{~mL}$ reached. Mixture reagent consisted of $100 \mu \mathrm{L}$ enzymes extract, $300 \mu \mathrm{L}$ substrates and $1500 \mu \mathrm{L}$ buffer. Reactions were started by addition of enzyme extract into TAME and buffer solution. The reaction mixture was then shaken and poured into a quartz cuvette. After the cuvette was placed in a spectrophotometry, absorbance was setup at zero conditions; absorbance measurement performed every 1 minute for 3 minutes. Hydrolysis of TAME was measured as the change in absorbance at a wavelength of $247 \mathrm{~nm}$ for 3 minutes at temperatures of $30{ }^{\circ} \mathrm{C}$. The activity of trypsin expressed as $\mathrm{U}=$ change Abs 247 $/ \mathrm{min} / \mathrm{mg}$ protein.

\section{Chymotrypsin activity essay}

Chymotrypsin activity was measured using N-benzoyl-L-tyrosine ethyl ester (BTEE) as a substrate (Lazzari et al., 2010). $2 \mathrm{mM}$ BTEE substrate was prepared by dissolving $31.4 \mathrm{mg}$ BTEE up to $50 \mathrm{~mL}$ to $50 \%$ methanol. $80.0 \mathrm{mM}$ Tris$\mathrm{HCl}$ buffer at $\mathrm{pH} 7.8$ containing $0.1 \mathrm{M}$ $\mathrm{CaCl}_{2}$ was prepared by dissolving $2.42 \mathrm{~g}$ Tris into double distilled water to a volume of $150 \mathrm{~mL}$, then added $55 \mathrm{~mL}$ of $5 \%(\mathrm{w} / \mathrm{v}) \mathrm{CaCl}_{2}$. The solution is then adjusted $\mathrm{pH}$ by adding a solution of $1 \mathrm{~N}$ $\mathrm{HCl}$ until the $\mathrm{pH}$ reached 7.8. The solution was then diluted to a volume of $250 \mathrm{~mL}$. The mixture reaction consisting of $100 \mu \mathrm{L}$ of enzyme extract, $1400 \mu \mathrm{L}$ substrate and $1500 \mu \mathrm{L}$ buffer. Reactions were started by addition of enzyme extract to the mixture of BTEE and buffer solution. The reaction mixture was then shaken and poured into a quartz cuvette. After the cuvette was placed in a spectrophotometry, absorbance was setup in zero condition; absorbance measurements performed every 1 minute for 3 minutes. BTEE hydrolysis was measured as a change in absorbance at a wavelength of $256 \mathrm{~nm}$ for 3 minutes at temperatures of $30{ }^{\circ} \mathrm{C}$. Chymotrypsin activity expressed as $\mathrm{U}=$ change Abs 256 $/ \mathrm{min} / \mathrm{mg}$ protein.

\section{Amylase activity essay}

Modification method of Klahan, Areechon, Yoonpundh, \& Engkagul, (2009) using 3,5-Dinitrosalicylic acid with the starch as substrate was used to measure amylase activity. The reagent of $0.1 \mathrm{M}$ Tris- $\mathrm{HCl}(\mathrm{pH}$ 8.1) was used as a buffer. Buffer 0.1 M Tris- $\mathrm{HCl}(\mathrm{pH} 8.1)$ was prepared by dissolving $1.212 \mathrm{~g}$ Tris into double distilled water to a volume of $80 \mathrm{~mL}$. The solution was then adjusted $\mathrm{pH}$ with $1 \mathrm{~N} \mathrm{HCl}$ solution drop by drop until the $\mathrm{pH}$ reached 8.1. Buffer solution was then diluted until they reached a volume of $100 \mathrm{~mL}$. $1 \%$ starch substrate was 
prepared by dissolving $1 \mathrm{~g}$ of starch to 100 $\mathrm{mL}$ of $0.1 \mathrm{M}$ Tris- $\mathrm{HCl}$ buffer solution containing $0.01 \mathrm{M} \mathrm{NaCl}$. The starch solution was then heated and boil for 5 minutes. Reagent 1\% 3,5-dinitrosalicylic acid (DNS) was prepared by dissolving $1.0 \mathrm{~g}$ DNS into $30 \mathrm{~mL}$ of double-distilled water, then add $40 \mathrm{~mL}$ of $1 \mathrm{~N} \mathrm{NaOH}$ and $30 \mathrm{~g} \mathrm{Na-K}$ tartrate $4 \mathrm{H}_{2} \mathrm{O}$, then added double-distilled water up to a volume of $100 \mathrm{~mL}$. Mixture Reaction consisting of substrate $(750 \mu \mathrm{L})$, buffer $(70 \mu \mathrm{L})$ and the enzyme extract $(50 \mu \mathrm{L})$ were incubated for $20 \mathrm{~min}$ at $37{ }^{\circ} \mathrm{C}$, and the reaction was stopped by addition of $1500 \mu \mathrm{L}$ of $1 \%$ DNS reagent. The mixture reaction was put into boiling water for 5 minutes. The same procedure was done on the blank tube except that enzyme extract was added after the $1 \%$ DNS reagent. The maltose as the product of hydrolysis of the substrate was determined by the standard curve of maltose at $540 \mathrm{~nm}$. Maltose standard curve made with maltose concentrations between 0.21 to $3.36 \mu \mathrm{mol} / \mathrm{mL}$. The activity of amylase was calculated as the amount of maltose released $(\mu \mathrm{mol})$ $/ \mathrm{min} / \mathrm{mg}$ protein extract.

\section{Cellulase activity essay}

Modification method of Savona et al. (2011) using 3,5-Dinitrosalicylic acid and substrate carboxymethylcellulose (CMC) were used to measure the cellulase activity. Reagent $0.1 \mathrm{M}$ sodium acetate ( $\mathrm{pH}$ 5.0) was used as a buffer. $0.1 \mathrm{M}$ sodium acetate buffer ( $\mathrm{pH}$ 5.0) was prepared by dissolving $578.3 \mathrm{mg}$ $\mathrm{C}_{2} \mathrm{H}_{3} \mathrm{O}_{2} \mathrm{Na}$ into double-distilled water to a volume of $80 \mathrm{~mL}$. Then set a $\mathrm{pH}$ buffer solution with added $178.5 \mathrm{mg}$ of glacial acetic acid until the $\mathrm{pH}$ reached 5.0 and the buffer was diluted with doubledistilled water until they reached a volume of $100 \mathrm{~mL}$. Substrate carboxymethyl cellulose $1 \%$ was prepared by dissolving $0.5 \mathrm{~g}$ of CMC in $50 \mathrm{~mL}$ acetate buffer solution. Reagent, $1 \%$ DNS was prepared by dissolving $1 \mathrm{~g}$ DNS, $0.2 \mathrm{~g}$ of phenol, $0.05 \mathrm{~g}$ of sodium sulfite and $20 \mathrm{~g}$ of $\mathrm{Na}-\mathrm{K}$ tartrate in $50 \mathrm{~mL}$ of $2 \% \mathrm{NaOH}$. DNS reagent was then diluted with doubledistilled water until they reached a volume of $100 \mathrm{~mL}$. Mixture Reaction consisting of substrate $(300 \mu \mathrm{L})$, buffer $(300 \mu \mathrm{L})$ and the enzyme extract $(60 \mu \mathrm{L})$ were incubated for $20 \mathrm{~min}$ at $40{ }^{\circ} \mathrm{C}$, and the reaction was stopped by addition of 900 $\mu \mathrm{L}$ of $1 \%$ DNS reagent. The mixture reaction was put into boiling water for 5 minutes. The same procedure was done on the blank tube except enzyme extract was added after the 1\% DNS reagent. The releasing amount of maltose from substrate were determined from a standard curve of maltose at $540 \mathrm{~nm}$. Maltose standard curve was prepared in the same manner as that used for the measurement of amylase activity. The activity of cellulase was calculated as the amount of maltose released $(\mu \mathrm{mol}) / \mathrm{min} / \mathrm{mg}$ protein extract.

\section{Statistical analysis}

Data of enzyme activity was analysis with One Way ANOVA, followed with post test using Least Significant Difference (LSD) at 0.05 significance level. Statistical analysis was performed using SPSS 18.0 package version of Windows software.

\section{RESULT AND DISCUSSION}

\section{Trypsin and chymotrypsin activities}

A significant difference of trypsin activity was observed among feeding levels $(\mathrm{P}<.0 .05)$ with the lowest activity in fish fed by $\mathrm{A}(0.34 \mathrm{~g}$ protein $+0.03 \mathrm{~g}$ fiber/day/100 $\mathrm{g}$ biomass). However, no statistical difference among trypsin activities on fish fed by B (1.01 g protein+0.10 g fiber/day/100 $\mathrm{g}$ biomass ), C $(1.69 \mathrm{~g}$ protein $+0.16 \mathrm{~g}$ fiber/day/100 $\mathrm{g}$ biomass) and D (2.36 g protein+0.23 $\mathrm{g}$ fiber/day/100 g biomass) (Figure 1). The results indicated that optimal trypsin activity on fish was fed by B (1.01 g protein $+0.10 \mathrm{~g}$ fiber/day/100 $\mathrm{g}$ biomass ).

Chymotrypsin activity among feeding levels showed a similar pattern 
with trypsin activity. It was significantly different among feeding levels $(\mathrm{P}<0.05)$ with the lowest chymotrypsin activity obtained from fish fed by A $(0.34 \mathrm{~g}$ protein $+0.03 \mathrm{~g}$ fiber/day/100 $\mathrm{g}$ biomass) and the highest activity was observed in fish fed by $\mathrm{B}(1.01 \mathrm{~g}$ protein $+0.10 \mathrm{~g}$ fiber/day/100 $\mathrm{g}$ biomass). However, there was no significant difference between fish fed by $\mathrm{C}(1.69 \mathrm{~g}$ protein $+0.16 \mathrm{~g}$ fiber/day/100 $\mathrm{g}$ biomass $)$ and by $\mathrm{D}(2.36 \mathrm{~g}$ protein $+0.23 \mathrm{~g}$ fiber/day/100 $\mathrm{g}$ biomass) (Figure 1). The changes in nutrient intake in this study resulted in the alteration of trypsin and chymotrypsin activities, which was indicated by the increase of trypsin and chymotrypsin activities in yellow fish rasbora fed by B (1.01 g protein $+0.10 \mathrm{~g}$ fiber/day/100 $\mathrm{g}$ biomass) compared to the activity of trypsin and chymotrypsin in fish fed by A (0.34 g protein $+0.03 \mathrm{~g}$ fiber/day/100 $\mathrm{g}$ biomass). The feed quantity of $1.01 \mathrm{~g}$ of protein $+0.10 \mathrm{~g}$ fiber/day/100 $\mathrm{g}$ biomass was optimum for yellow rasbora to live because the further addition of protein and fiber content did not give specific activities of protease significantly.

In this study, we used TAME as substrate and change of absorbance as unit activities, but previous studies used N-benzoyl-DL-arginine $\quad p$-nitroanilide (BAPNA) as substrate and $p$-nitroaniline as the standard unit of activities. Therefore, our result could not be compared to previous studies, such as the study from Betta splendens (Thongprajukaew et al., 2010), Silurus meridionalis (Zeng, Li, Fu, Can, \& Zhang, 2012), Oreochromis niloticus (AbdelWarith, Younis, Al-Asgah, \& Abdualla, 2013) and Poecilia reticulata (Thongprajukaew \& Kovitvadhi, 2013).

Differences among protease activities were due to differences in nutrient intake as observed in this study that was also found in Labeo bata (Mondal, Kaviraj, \& Mukhopadhyay, 2012), Megalobrama amblycephala (Habte-Tsion et al., 2013) and Labeo rohita (Kumar, Jain, Munilkumar, Sahu, $\&$ Pal, 2013).

So it seems that yellow rasbora only responded to increased level of up to 1.01 $\mathrm{g}$ protein $+0.10 \mathrm{~g}$ fiber/day/100 g biomass because it did not increase trypsin and chymotrypsin activities at upper levels. The capacity of digestion and absorption of proteins was due to the increase intake of protein in a feed (Karasov, Mart'inez del Rio, \& Caviedes-Vidal, 2011).

Chymotrypsin activity was higher than trypsin activity resulted in low trypsin and chymotrypsin ratio (the ratio of $\mathrm{T} / \mathrm{C}$ ). The $\mathrm{T} / \mathrm{C}$ ratio in this study ranged from 0.56 to 1.69 (Figure 2).

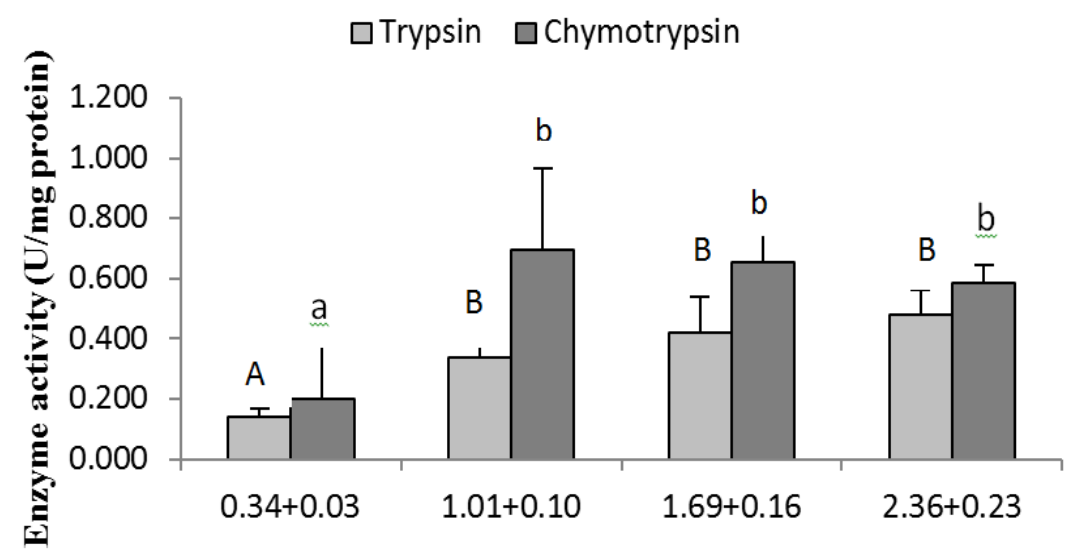

Feeding levels (g protein $+\mathrm{g}$ fiber)/day/100 $\mathrm{g}$ biomass

Figure 1. Mean (+S.D) trypsin and chymotrypsin activities of yellow rasbora at different feeding levels. Mean with different superscript was different significantly $(\mathrm{P}<0.05)$. 


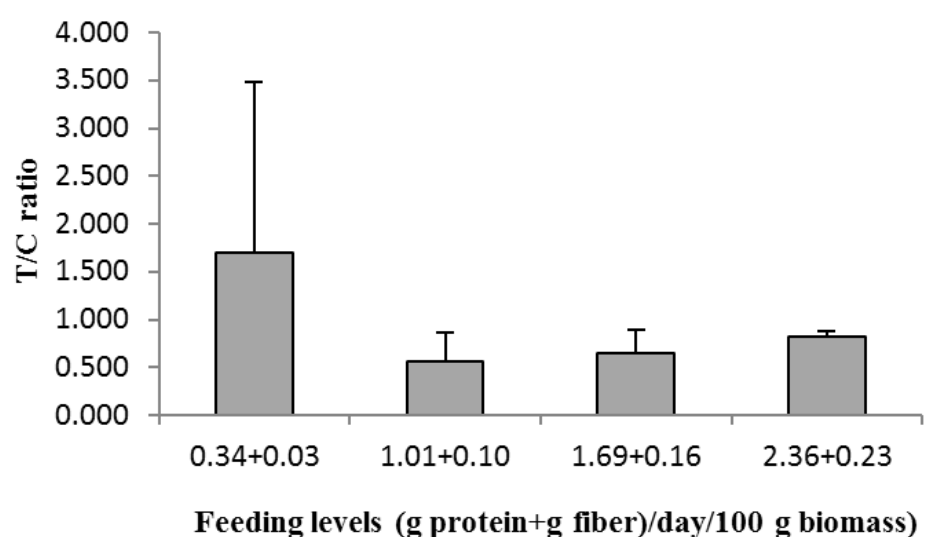

Figure 2. Mean (+S.D) trypsin/chymotrypsin ratio of yellow rasbora at different feeding levels.

The trypsin / chymotrypsin (T/C) ratio was not different significantly among feeding levels $(\mathrm{P}>0.05)$. The $\mathrm{T} / \mathrm{C}$ ratio in this study was lower than that obtained in Salmo salar (Rungruangsak-Torrissen, Moss, Andresen, Berg, \&Waagbo 2006) and Poecilia reticulate (Thongprajukaew \& Kovitvadhi, 2013), but higher than those obtained at Oreochromis mossambicus (Chan et al. 2007). The low $\mathrm{T} / \mathrm{C}$ ratio at all feeding levels might reflect a low growth rate of yellow rasbora, because the $\mathrm{T} / \mathrm{C}$ ratio is an indicator of growth rate. The $\mathrm{T} / \mathrm{C}$ ratio often related to feeding efficiency and growth rate (Rungruangsak-Torrissen et al., 2009; Rodiles et al., 2012).

\section{Amylase activity}

In this study, amylase activity ranged from 0.83 to $0.86 \mathrm{U} / \mathrm{mg}$ protein (Figure 3) and showed no significant differences among feeding levels ( $\mathrm{P}>$ $0.05)$. Amylase activity obtained in this study was lower than previous studies on Cyprinidae (Al-Tameemi et al., 2010), giant catfish, Pangasianodon gigas Chevey (Tongsiri et al., 2010), but was higher than on carnivorous fish Glyptosternum maculatum (Siluriformes) (Xiong et al., 2010).

No significant differences in amylase activity in increasing the quality and quantity of nutrients in this study also occurred in previous studies on Seriola lalandi (Bowyer, Qin, Adams, Thomson, \& Stone, 2012), and Rutilus rutilus (Soleimani, Hoseinifar, Merrifield, Barati, \& Abadi, 2012), but the different responses found at Dentex dentex (PerezJimenoz et al., 2009), Rhamdia quelen (Lazzari et al., 2010), Labeo bata (Mondal et al., 2012), Megalobrama amblycephala (Habte-Tsion et al., 2013) and Labeo rohita (Bhilave Nalawade, \& Kulkarni, 2014).

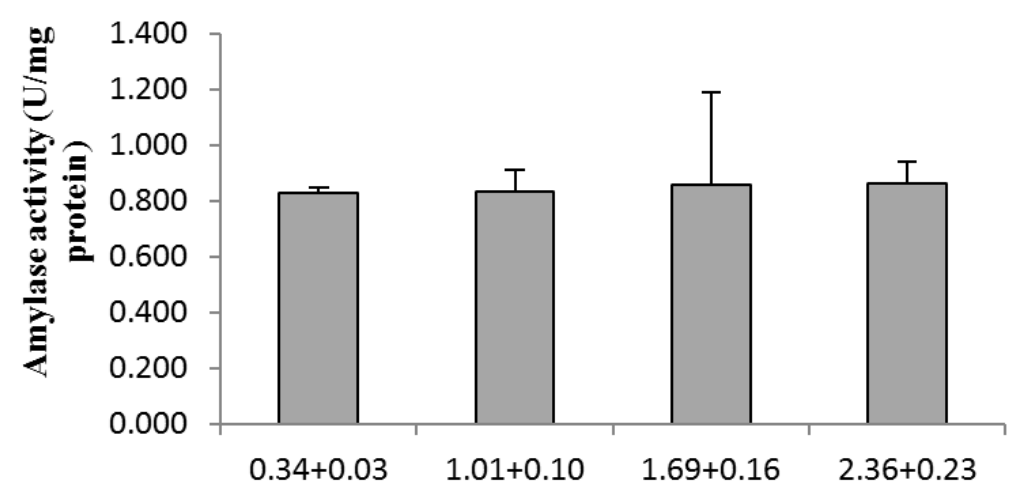

Feeding levels (g protein $+\mathrm{g}$ fiber)/day/100 $\mathrm{g}$ biomass)

Figure 3. Mean (+S.D) amylase activity of yellow rasbora at different feeding levels. 


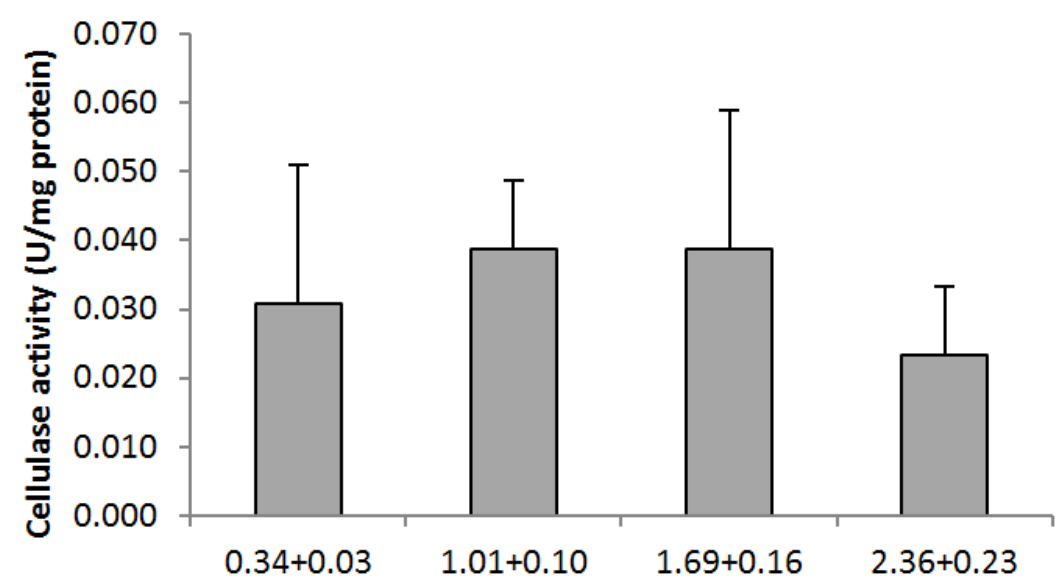

Feeding levels (g protein $+\mathrm{g}$ fiber)/day/100 $\mathrm{g}$ biomass)

Figure 4. Mean (+S.D) cellulase activity of yellow rasbora at different feeding levels.

The low amylase activity in this study and the differences in the category of feed suspected to cause no significant difference of amylase activity. Yellow rasbora, Rasbora lateristriata Blkr., is a member of Cyprinidae, and species differences also seem to produce differences in the ability of fish to digest starch.

Some Cyprinidae were omnivorous fish, like yellow rasbora (Sulistiyarto, 2012), so it has a lower capacity to digest carbohydrates than herbivorous. It seems that changes in feed intake were not significantly altered amylase activity.

\section{Cellulase activity}

Cellulase activity in this study was measured with CMC substrates ranging from 0.02 to $0.04 \mathrm{U} / \mathrm{mg}$ protein (Figure 4) and showed no significant difference among feeding levels $(\mathrm{P}>0.05)$. Cellulase activity obtained in this study was higher than in previous studies on carnivorous fish such as Parachanna (Channa) obscura and Gymnarchus niloticus, but was lower than tilapia, Oreochromis niloticus (Fagbenro et al. , 2005) and the giant catfish, Pangasianodon gigas (Tongsiri et al., 2010). The low population of microbial symbioses in the lumen gut of yellow rasbora is believed to be the cause of low activity of cellulose, so it does not appear to have changed significantly with the increase of feed intake levels. The existence of cellulolytic bacteria on fish omnivores and carnivores have the ability to digest fiber because it generally consumes invertebrates that contain cellulose-digesting microbes (Kar \& Ghosh, 2008). Therefore, yellow rasbora reared in the concrete tank do not have the opportunity to consume invertebrates, resulting in low activity of cellulase in its digestion tract. Fish generally do not secrete cellulase, and therefore the ability to digest cellulose in fish was highly dependent on the presence of microbial symbioses in lumen digestion of fish (Ganguly, 2013).

\section{CONCLUSION}

Capacity to digest protein increased, but the ability to digest starch and fiber does not change with the increase of feeding levels. Feed containing $1.01 \mathrm{~g}$ protein $+0.10 \mathrm{~g}$ fiber/day/100 $\mathrm{g}$ fish biomass was the optimal feeding levels for yellow rasbora.

\section{ACKNOWLEDGMENTS}

This research was conducted with co-funded by Indonesian Ministry Research and Higher Education through competitive grants Hibah Doktor DIKTI 2016. Special thanks go to Dr. Agus Nuryanto, MSi. and Adi Amurwanto MSc., Lecturer of Biology Faculty, 
Unsoed, for his contribution editing the manuscript.

\section{REFERENCES}

Abdel-Warith, A.W.A., Younis, E.M., AlAsgah, Abdualla, N., 2013. Influence of dietary inclusion of full-fat soybean meal and amino acids supplementation on growth and digestive enzymes activity of Nile tilapia, Oreochromis niloticus. Turkish Journal of Fisheries and Aquatic Sciences, 13: 69-77.

Al-Tameemi, R., Aldubaikul, A.\&Salman, N.A., 2010. Comparative study of $\alpha$ amylase activity in three cyprinid species of different feeding habits from soutthern Iraq. Turkish Journal of Fisheries and Aquatic Sciences, 10: 411-414.

Astuti, E.H., 2012. Dynamics of reproduction activity and population of lunjar (Rasbora argyrotaenia) as reference conservation efforts. Thesis. Graduate Programs, Faculty of Biology,Universitas Jenderal Soedirman. Purwokerto.

Bhilave, M.P., Nalawade, V.B. \& Kulkarni, J.J., 2014. Amylase activity of fingerlings of freshwater fish Labeo rohita fed on formulated feed. International Journal of Fisheries and Aquatic Studies, 2(1): 53-56.

Bowyer, J.N., Qin, J.G., Adams, L.R., Thomson, M.J.S. \& Stone, D.A.J., 2012. The Response of digestive enzyme activities and gut histology in yellowtail kingfish (Seriola lalandi) to dietary fish oil substitution at different temperatures. Aquaculture, 368-369: 19-28.

Chan, C.R., Lee, D.N., Cheng, Y.H., Hsieh, D.J.Y., \&Weng, C.F., 2007. Feed Deprivation and Re-feeding on Alterations of Proteases in Tilapia Oreochromis mossambicus. Zoological Studies, 47(2): 207-214.
Day, R.D., German, D.P., Manjakasy, J.M., Farr, I., Hansen, M.J. \&Tibbetts, I.R., 2011. Enzymatic digestion in stomachless fishes : how a simple gut accomodates both herbivory and carnivory. Journal of Comparative Physiology B.181: 603-613.

Debnath, D., Pal, A.K., Sahu, N.P., Yengkokpam, S., Baruah, K., Choudhury, D. \& Venkateshwarlu, G., 2007. Digestive enzymes and metabolic profile of Labeo rohita fingerlings fed diets with different crude protein levels. Comparative Biochemestry and Physiology, Part B. 147: 107-114.

Dina, R., Boer, M. dan Butet, N.A., 2011. Profile size length and gonad maturity level bada fish (Rasbora argyrotaenia) at different capture device in lake Maninjau.Oseanologi dan Limnologi di Indonesia. 37(1): 105-118.

Fagbenro, O., Adedire, O., Fateru, O., Owolabi, I., Ogunlana, O., Akanbi, B., Fasanmi, T. \& Ayo-Amu, P., 2005. Digestive enzyme assays in the gut of oreochromisniloticus linnaeus 1757, Parachanna (Channa) obscura Gunther 1861 and Gymnarchus niloticus Cuvier 1829. Animal Research International, 2(2): 292 - 296

Ganguly, S., 2013. Digestive physiology and role gastrointestinal enzymes in fish gut : A specialized Review. International Journal of Recent Biotechnology, 1(2): 15-16.

German, D.P., Horn, M.H. \&Gawlicka, A. 2004. Digestive enzyme activities in herbivorous and carnivorous prickleback fishes (Teleostei: Stichaeidae): Ontogenetic, Dietary and Phylogenetic effects. Physiological and Biochemical Zoology, 77(5): 789-804.

German, D.P., 2009. Do herbivorous minnows have "plug-flow reactor" guts ? evidence from digestive 
enzyme activities, gastrointestinal fermentation, and luminal nutrient concentrations. Journal of Comparative Physiology $\quad$ B. 179: 759-771.

Habte-Tsion, H.M., Liu, B., Ge, X., Xie, J., Xu, P., Ren, M., Zhou, Q., Pan, L. \& Chen, R., 2013. Effects of dietary protein level on growth performance, muscle composition, blood composition, and digestive enzyme activity of wuchang bream (Megalobrama amblycephala) fry. The Israeli Journal of AquacultureBamidgeh, IJA_65.2013.925, 9 pages.

Kar, N. \& Ghosh, K., 2008. Enzyme producing bacteria in the gastrointestinal tracts of Labeo rohita (Hamilton) and Channa punctatus (Bloch). Turkish Journal of Fisheries and Aquatic Sciences, 8: 115-120.

Karasov, W.H.,Mart'inez del Rio, C.\&Caviedes-Vidal, E., 2011. Ecological Physiology of Diet and Digestive Systems. The Annual Review of Physiology, 73: 69-93.

Kishimura, H., Klomklao, S., Benjakul, S. \& Chun, B.S., 2008. Characteristics of trypsin from the pyloric ceca of walleye Pollock (Theragra chalcogramma). Food Chemestry, 106: 194-199.

Klahan, R., Areechon, N., Yoonpundh, R. and Engkagul, A., 2009. Characterization and activity of digestive enzymes in different sizes of nile tilapia (Oreochromis niloticus L.).

The Kasetsart Journal,Natural

Science 43 : 143 - 153.

Kraugerud, O.F., Penn, M., Storebakken, T., Refstie, S., Krogdahl, A. \& Svihus, B., 2007. Nutrient digestibilities and gut function in Atlantic salmon (Salmo salar) fed diets with cellulose or non-starch polysaccharides from soy. Aquaculture, 273: 96-107.
Kumar, P., Jain, K.K., Munilkumar, S., Sahu, N.P.\&Pal, A.K., 2013. Effect of feeding normal and low protein diet alternately to Labeo rohita fingerlings on growth performance and biochemical composition. International Journal of Science and Knowledge, 2(1): 3-13.

Langeland, M., Lindberg, J.E. and Lundh, T., 2013. Digestive enzyme activity in eurasian perch (Perca fluviatilis) and artic charr (Salvelinus alpinus). Aquaculture Research \& Development. 5(1): 1-8.

Lazzari, R., Neto,J.R., Pedron, F.A., Loro, V.L., Pretto, A.\&Gioda, C.R., 2010. Protein sources and digestive enzyme activities in jundia (Rhamdia quelen). Sci. Agric. (Piracicaba, Braz.), 67(3): 259-266.

Mondal, K., Kaviraj, A.\&Mukhopadhyay, P.K., 2012. Effects of partial replacement of fishmeal in the diet by mulberry leaf meal on growth performance and digestive enzyme activities of Indian minor carp Labeo bata. International Journal of Aquatic Science, 3 (1): 72-83.

Namulawa, V.T., Kato, C.D., Rutaisire, J., Britz, P.J., Beukes, N., Pletschke, B.I. and Whiteley, C., 2013. Enzyme activity in the Nile perch gut: Implications to Nile perch culture. International Journal of Fisheries and Aquaculture. 5(9): 221-228.

Nasri, R., Younes, I., Lassoued, I., Ghorbel, S., Ghorbel-Bellaaj, O. and Nasri, M., 2011. Digestive alkaline proteases from Zosterisessor ophiocephalus, Raja clavata andScorpaena scrofa: Characteristics and aplication in chitin extraction. Research Journal of Amono Acids. doi:10.406/2011/913616.

Odedeyi, D.O., 2007. Digestive enzymes in the gut of snakehead fish, Parachanna obscura (Gunter, 1861) (Chanidae) in river Ose South 
Western Nigeria. Journal of Fisheries International. 2(2): $178-$ 181.

Odedeyi, D.O. \&Fagbenro, O.A., 2010. Feeding habits and digestive enzymes in the gut of Mormyrus rume (Valenciennes 1846) (Osteichthyes Mormyridae). Tropical Zoology. 23: 75-89.

Perez-Jimenez, A., Cardenete, G., Morales, A.E., Garcia-Alcazar, A., Abellan, E. \& Hidalgo, M.C., 2009.Digestive enzymatic profile of Dentexdentexand response to different dietary formulations. Comparative Biochemistry and Physiology, Part A, 154: 157-164

Prasad, G. \&Suneesha, I., 2013. Digestive enzyme characterization of threatened yellow catfish Horabagrus brachysoma (Gunter) (Teleostes: Siluriformes: Horabagridae) at two life stages. Journal of Aquatic Biology \& Fisheries. 1(1\&2): 83-89.

Prasertsan, P. \&Prachumratana, T., 2008. Comparison and selection of protease and lipase sources from viseral organs of three tuna species. Songklanakarin

Journal of Science and Technology 30(1): 73-76.

Rodiles, A., Santigosa, E., Herrera, M., Hachero-Cruzado, I., Cordero, M.L., Martinez-Llorens, S., Lall, S.P. \&Alarcon, F.J., 2012. Effect of dietaary protein level and source on digestive proteolytic enzyme activity in juvenile Segalese sole, Solea senegalensis Kaup 1850. Aquatic Int. DOI 10.1007/s10499012-9508-6.

Rosadi, E., Endang, Y.H., Setyohadi, D. \&Bintoro, G., 2014. Distribution, composition and abiotic enviroment of silver Rasbora (Rasbora argyrotaenia $\mathrm{Blkr}$.) fish in upstream areas of Barito watershed, South
Kalimantan. Journal of Enviroment and Ecology. 5(1): 117-126.

Rungruangsak-Torrisen, K., Moss, R., Andresen, L.H., Berg, A. \&Waagbo, R., 2006. Different expression of trypsin and chymotrypsin in relation to growth in Atlantic salmon (Salmo salar L.). Fish Physiology and Biochemistry. 32: 7-23.

Rungruangsak-Torrissen, K. Stien, L.H., Daae, B.S., Vagseth, T., Thorsheim, G.B., Tobin, D. \& Ritola, O., 2009. Different dietary levels of protein to lipid ratio affected digestive efficiency, skeletal growth and muscle protein in raibow trout families. Scholarly Research Exchange. DOI: 10.3814/2009/709529

Sankar, H., Jose, J., Varadarajan, R., Bhanu,S.V. Joy, S. \&Philip, B., 2014. Functional zonation of different digestive enzymes in Etroplus suratensis and Oreochromis mossambicus. International Journal of Scientific and Research Publications. 4(5): 15.

Savona, B., Tramati, C. \& Mazzola, A., 2011. Digestive enzymes in larvae and juveniles of farmed sharpsnout seabream (Diplodus puntazzo) (Cetti, 1777). The Open Marine Biology Journal. 3: 47-57.

Skea, G.L., Mounfort, D.O. \&Clements, K.D., 2007. Contrasting digestive strategies in four New Zealand herbivorous fishes as reflected by carbohydrase activity profiles. Comparative Biochemestry and Physiology, Part A. 146: 63-70.

Soleimani, N., Hoseinifar, S.H., Merrifield, D.L., Barati, M. \& Abadi, Z.H., 2012. Dietary supplementation of fructooligosaccharide (FOS) improves the innate immune response, stress resistance, digestive enzyme activities and growth 
performance of Caspian roach (Rutilus rutilus) fry. Fish \& Shellfish Immunology, 32: 316-321.

Sulistiyarto, B., 2012. Length-weight relationship, condition factor, and food composition of Seluang fish(Rasbora argyrotaenia $\mathrm{Blkr}$ ) in Rungan River Flood Plain, Central Kalimantan. Jurnal Ilmu Hewani Tropika. Vol 1(2): 62-66

Thongprajukaew, K., Kovitvadhi, U., Engkagul, A. \&RungruangsakTorrissen, K., 2010. Temperature and $\mathrm{pH}$ characteristics of amylase and lipase at different development stages of siamese fighting fish (Betta splendens Regan, 1910). The Kasetsart Journal,Natural Science 44: 210-219.

Thongprajukaew, K., Kovitvadhi, U., Kovitvadhi, S., Somsueb, P. \& Rungruangsak-Torrissen, K., 2011. Effects of different modified diets on growth, digestive enzyme activities and muscle compositions in juvenile Siamese figting fish (Betta splendens Regan, 1910). Aquaculture, 322-323: 1-9.

Thongprajukaew, K. \& Kovitvadhi, K., 2013.Effects of sex on characteristics and expression levels of digestive enzymes in the adult guppy Poecilia reticulate. Zoologycal Studies, 52(3): 1-8.
Tongsiri, $\quad$ S., $\quad$ Mang-Amphan, K.\&Peerapornpisal, Y., 2010. Characterization of amylase, cellulase and proteinase enzyme in stomach and intestin of the mekong giant catfish fed with various diets consisting of Spirulina. Current Research Journal of Biological Sciences, 2(4): 268-274.

Xiong, D.M., Xie, C.X., Zhang, H.J.\&Liu, H.P., 2009. Digestive enzymes along digestive tract of a carnivorous fish Glyptosternum maculatum (Sisoridae, Siluriformes). Journal of Animal Physiology and Animal Nutrition. 95: 56-64.

Yufera, M., Moyono, F.J., Astola, A., Pousau-Ferreira, P. \&MartinezRodriguez, G., 2012. Acidic digestion in teleost : Postprandial and circadian pattern of gastric $\mathrm{pH}$, pepsin activity, and pepsinogen and proton pump mRNAs expression. PLOS ONE 7(3): e 33687. doi : 10.1371/journal.pone. 0033687.

Zeng, L.Q., Li, F.J., Fu, S.J., Can, Z.D. \& Zhang, Y.G., 2012. Effect of feeding on the function and structure of the digestive system in juvenile southern catfish (Silurus meridionalis Chen). Fish Physiology and Biochemistry, $\quad 38$ : 1459-1475. 